\title{
Lawsuits Allege Price Fixing by Generic Drug Makers
}

Two years after high generic drug prices became a public controversy, Reuters is reporting that 20 states filed a lawsuit Thursday against Mylan, Teva Pharmaceuticals and four other generic drug makers (1). The suit alleges the companies conspired to fix prices or allocated markets to prop up prices. The civil lawsuit, led by antitrust investigators in Connecticut, comes one day after the U.S. Department of Justice filed criminal charges against two former executives of the generic drug maker, Heritage. The states attorneys general asked the court to order the companies to disgorge ill-gotten gains, which were not defined, pay attorneys' fees and stop collusion. Of the states in the Southwest only Nevada is participating in the lawsuit.

The cases are part of a broader generic drug pricing probe that remains under way at the state and federal level, as well as in the U.S. Congress. In 2014, media reports of sharply rising drug prices led to Congressional hearings. "We believe that this is the tip of the iceberg," Connecticut Attorney General George Jepsen told Reuters in an interview. "Price fixing in the generic industry is widespread and pervasive, and it involves many other drugs and a number of other companies."

Both former Heritage CEO Jeffrey Glazer and former Heritage Vice President of Commercial Operations Jason Malek are expected to plead guilty. According to Reuters, it is typical for the Justice Department to file one lawsuit about an ongoing issue and use evidence from those defendants to build subsequent cases against others. Several companies have publicly disclosed receiving subpoenas from the Justice Department related to generic drug pricing including Mylan, Allergan, Lannett, Impax, Par, Sun and Mayne.

The drugs involved in the Justice Department lawsuit include two older drugs, doxycycline hyclate and glyburide. Doxycycline rose from $\$ 20$ for 500 tablets to $\$ 1,849$ between October 2013 and May 2014.

Richard A. Robbins, MD

Editor, SWJPCC

\section{Reference}

1. Bartz D, Lynch SN. U.S. states sue Mylan, Teva, others for fixing drug prices. Reuters. December 16, 2016. Available at: http://www.reuters.com/article/ususa-drugpricing-idUSKBN14420C (accessed 12/17/16). 